\title{
Administrative Tradition and Management Reforms: \\ A Comparison of Agency Chief Executive Accountability in Four Continental Rechtsstaat Countries
}

Tobias Bach, Sandra van Thiel, Gerhard Hammerschmid, Reto Steiner

This is the post-print (i.e. final draft post-refereeing) version of the following article:

Bach, T., van Thiel, S., Hammerschmid, G., \& Steiner, R. (2017). Administrative tradition and management reforms: a comparison of agency chief executive accountability in four Continental Rechtsstaat countries. Public Management Review, 19(6), 765-784. doi: 10.1080/14719037.2016.1210205

\footnotetext{
Abstract:

This article investigates perceived accountability patterns of national agencies' chief executives in four countries with a Rechtsstaat tradition and tests theoretical expectations about potential tensions between managerial reforms and administrative values using survey data $(\mathrm{N}=453)$. All countries combine old and new forms of accountability requirements, while legal and financial accountability have not been replaced with results accountability. Switzerland and The Netherlands score highest on results accountability, though in combination with legal and financial accountability, which are dominant in Germany and Austria. Nation-specific characteristics seem more important for core values of public administration than generic characteristics of the Rechtsstaat model.
} 


\section{Administrative Tradition and Management Reforms: \\ A Comparison of Agency Chief Executive Accountability in Four Continental Rechtsstaat Countries}

\section{Introduction}

Twenty-five years ago, Hood (1991) criticized the universalistic aspirations of the New Public Management (NPM) as a panacea to all kinds of illnesses plaguing public bureaucracies. In particular, the claim of early NPM advocates that industrialized countries are inevitably converging towards a single model has been shown to have limited empirical validity (Christensen and Lægreid 2001; Lynn 2006; Pollitt and Bouckaert 2011; Suleiman 2003). National institutions, traditions and legacies have affected and 'hybridized' reforms like agencification (Verhoest et al. 2012). However, despite these differences, the convergence metaphor continues to serve as a "useful myth" (Pollitt 2001) to confer legitimacy to administrative reforms.

A key explanation for divergence is that administrative reforms are shaped by administrative traditions shared by "families of nations" (Painter and Peters 2010; Pollitt and Bouckaert 2011; Proeller and Schedler 2005). Administrative traditions consist of 'ideas about the nature of government' which define what types of reforms are considered appropriate, and of 'institutions of government' which define the rules of the game for reform activities (Yesilkagit 2010, 151). As a consequence, generic reform ideas are assumed to undergo a "cultural screening" and are more likely to be adopted if they match with the dominant ideas and values of the local context (Smullen 2010; Christensen and Lægreid 2001).

This article aims to study the interaction of administrative traditions and reform ideas in four countries belonging to the Rechtsstaat tradition (Painter and Peters 2010; Ziller 2012): Austria, Germany, the Netherlands and Switzerland. The Rechtsstaat tradition is often considered as an obstacle towards managerial reforms (Hammerschmid and Meyer 2005). Pollitt and Bouckaert (2011) argue that Rechtsstaat systems are "stickier" and slower to reform, as reforms usually require legal 
changes. Moreover, civil servants predominantly trained in administrative law may find it difficult to shift to a managerial or performance-oriented perspective. This article develops and empirically tests theoretical expectations about tensions and trade-offs between the underlying values of NPM reforms and the Rechtsstaat tradition (cf. Frederickson 1996; Hood 1991; Olsen 2006; Lynn 2006; Painter and Peters 2010; Pollitt and Bouckaert 2011).

The empirical focus is on the relevance of distinct administrative values in relations of 'upward accountability' (Verschuere et al. 2006) or 'vertical accountability' (Bovens 2010) between chief executives of semi-autonomous agencies ("who is accountable") and their hierarchical superiors (i.e. parent ministries; "to whom") at the national level. Also, we are interested in the content of accountability ("for what") as perceived by those actors rendering account to their superiors. The central research questions are: Which accountability patterns of agency chief executives can be observed at the national level in the four countries? To what extent are these patterns similar to each other? Do they reflect variation in national trajectories of administrative reforms? Finally, to what extent do patterns of perceived accountability vary according to organizational characteristics, as opposed to national context?

The next section sketches the Rechtsstaat tradition and its effects on agencification and accountability arrangements between agencies and ministries. A number of hypotheses will be formulated about expected similarities - or lack thereof - between countries and agencies, which will then be put to the test using survey data $(\mathrm{N}=453)$ collected in the four countries. After presenting the results, we draw conclusions and discuss our findings.

\section{The Continental Rechtsstaat Tradition, Administrative Values, and Management Reforms}

It has almost become a truism that contextual conditions for public management reforms in Continental European countries differ substantially from their counterparts in the Anglo-American parts of the world (Christensen and Lægreid 2001; König 2000; Lynn 2006; Pollitt and Bouckaert 2011; Suleiman 2003). These differences can be analytically grasped by the notion of administrative 
tradition, which distinguishes the Rechtsstaat tradition from the common law tradition (Painter and Peters 2010). The idea of a sovereign bound by rules applied in an objective and equal manner by independent and politically neutral administrators is central for the Continental European Rechtsstaat tradition (Ziller 2012). A key feature of this tradition is an internally consistent hierarchy of law and a system of administrative courts (König 2000). In consequence, public management in Rechtsstaat countries is traditionally understood as the application of law, as administrative decisions are always potentially subject to judicial review.

This article analyzes administrative traditions and administrative reforms through the analytical lens of administrative values (Frederickson 1996; Hood 1991; Lynn 2006; Olsen 2006). Our main argument is that administrative traditions and administrative reforms embody particular administrative values which stand for a distinct model of "good administration", and that these values imply trade-offs and incompatibilities (Hood 1991; Pollitt and Bouckaert 2011). Administrative traditions contain distinct expectations about good administration which are embodied in the actor orientations of policy makers (Yesilkagit 2010). Accordingly, the latter will use these standards as a benchmark when holding public officials to account. However, administrative traditions are not immutable, and reforms may challenge dominant administrative values (Lynn 2006; Painter and Peters 2010). We will get back to this interplay of traditions and reforms when developing our hypotheses.

Although faced with various starting conditions, many developed countries embarked - at least rhetorically - on the modernization recipes of the NPM (Christensen and Lægreid 2001; Pollitt 2001; Pollitt and Bouckaert 2011; Suleiman 2003). In this context, several authors have argued that NPM is incompatible with traditional public administration as a result of a clash of the fundamental values underlying both models. In a widely-cited article, Hood (1991) questions the universalistic nature of NPM on the grounds that the reform model is based on a distinct set of administrative values which are in conflict with other values associated with traditional administration. The main emphasis of NPM is on frugality or the 'matching of resources to tasks for given goals' (Hood 1991, 11) as the standard for good administration and control over the output of the bureaucracy as a necessary ingredient to assess efficiency. Another set of values are honesty and fairness of administrative 
conduct. These values put a premium on "the proper discharge of duties in procedural and substantive terms' (Hood 1991, 13), which coincides with an emphasis on procedural correctness or 'how the job is done' rather than output control. A third standard of administrative success is the resilience and reliability of bureaucracy in adverse conditions such as catastrophes. The standard of assessing success is the robustness of service provisions and the provision of security and survival, which is again associated with an emphasis on input and processes.

Hood (1991) argues that frugality, honesty, and resilience cannot be satisfied at the same time. Moreover, he points out that NPM tends to assume honesty and neutrality as given values, which leads to the empirical question whether frugality (i.e. NPM reforms) crowds out honesty and resilience in the long run. In a similar vein, Frederickson $(1996,266)$ stresses the trade-offs between the rationalities of mission-driven government and rule-driven government: 'If efficiency and flexibility are preferred, then a rationality of tossing out rules and substituting the superiority of mission is called for.' A dominance of output-orientation is likely to result in 'more efficient innovative, and flexible government, and government that is less fair and more open to abuse and corruption' (Frederickson 1996, 266).

Olsen (2006) emphasizes the difficult balancing of administrative values too, and challenges the universalistic nature of principles of organizational design which he claims are "partial, time- and space-bound interpretations' (Olsen 2006, 14). Moreover, he argues that bureaucratic organizations inculcate genuinely democratic values such as fairness and equality into their members. Likewise, Suleiman (2003) stresses the problematic consequences of NPM reforms on democratic governance and emphasizes that managerial reforms imply 'skepticism about the existence of a public-service institution' (Suleiman 2003, 47).

This article contributes to the question how competing administrative values are balanced in a tradition of rule-bound administration. We empirically test the widespread assumption that managerial reforms' focus on performance and measuring outputs is at odds with the Rechtsstaat tradition with its strong emphasis on hierarchy and legality i.e. formal rules and procedures (Lynn 2006; Pollitt and Bouckaert 2011; Proeller and Schedler 2005). 


\section{Agencification in Four Continental European Countries}

Agencification is part of the complex of NPM reforms (Pollitt and Bouckaert 2011; Smullen 2010; Verhoest et al. 2012). These reforms were based on the expectation that breaking up government departments by delegating executive and regulatory tasks to single-purpose agencies and introducing business-like instruments would boost performance. In exchange for more autonomy, agencies would however also have to report about their performance (Moynihan and Pandey 2006). This section gives a short overview of agencification in the four countries under study. ${ }^{1}$

Albeit looking back to a long tradition of public agencies and authorities outside core ministerial departments, agencification reforms did not become popular in Austria until the 1990s. They involved the creation of legally independent but fully government-owned incorporated organizations through statutory law. Such corporatizations based both on public and private law became increasingly popular to escape from supposedly inflexible budget and civil service laws but also allowed to hive-off public sector deficits (Hammerschmid, Krischock and Steigenberger 2012). The "corporatization fever" within the Austrian federal government instigated some controversy about accountability and fragmentation issues, to which the government responded by introducing a new type of agency status which grants selected government units a more flexible and discretionary use of financial resources on the basis of statutory performance agreements. In contrast to corporatizations, these semi-autonomous agencies remain within the federal legal framework.

Similarly, Germany has a long tradition of delegation to public law based organizations outside ministerial departments. A large number of federal agencies was created in the post-war period, whereas since the 1990s most reforms involved mergers of existing organizations, as well as the formal autonomization of a limited number of public law agencies through changing their legal status from semi-autonomous to legally independent organizations (Bach and Jann 2010). The rhetoric of managerial reforms came later to Germany than to most other Western European countries, and their implementation remained rather limited, at least at the federal level (Pollitt and Bouckaert 2011).

\footnotetext{
${ }^{1}$ For more detailed analyses of trajectories of agency reforms in each country, see the respective chapters in Verhoest et al. (2012).
} 
Most importantly, administrative reforms have a strong sectoral focus, which is related to the strong departmental principle, according to which parent ministries decide how much autonomy agencies can have, and how they are held accountable.

Steiner and Huber $(2012,191)$ typify the Swiss pattern of administrative reforms as 'evolutionary change' where 'radical reforms rarely occur.' That said, since the 1990s several public law bodies were granted more budgetary autonomy, and performance contracts were introduced for those semi-autonomous organizations. In addition, legally independent units (public or private law) were created in the 1990s, including large organizations such as the Swiss Railways and the Swiss Post. Though increased autonomy from politics was the main driver of these developments, government and parliament are reluctant to fully switch to a managerial steering model because they prefer to retain the possibility to intervene directly. However, the parallel existence of "old" and "modern" agencies has created tensions (Steiner and Huber 2012), and the government has recently embarked on a comprehensive reform of governing arrangements for agencies.

The Netherlands has a longstanding tradition in the creation of agencies (Yesilkagit and Van Thiel 2012). However, under influence of NPM in the 1980s, the number of agencies skyrocketed, in particular the legally independent ZBOs (zelfstandige bestuursorganen). Similar to Austria this led to a hot political debate, fuelled by reports about poor legal and accountability arrangements. The government responded by creating a new type of semi-autonomous agency (agentschap) that would remain closer to the government (limited autonomy, full ministerial accountability). The Dutch debate on agencies focuses on ministerial accountability for ZBOs, which is limited. However, there are no generic guidelines on the boundaries of this (limited) accountability. Parent ministries can decide individually how they monitor and control agencies (Yesilkagit and Van Thiel 2012). The arrangement is laid down in some form of contract or protocol. In sum, there is a large variety in agency arrangements, despite the advent of a charter law for ZBOs (Overman, Van Thiel and Lafarge, 2014).

After this brief outline of agency reforms in the four countries, we will now develop theoretical expectations regarding the impact of agency reforms on the accountability of agency chief executives in countries with a Rechtsstaat tradition. 


\section{Managerial Reforms, Administrative Values, and Accountability}

Accountability is an important concept in the NPM paradigm, although in different ways and for different reasons (Aucoin and Heintzman 2000; Bovens 2010; Lægreid 2014; Schillemans 2008). On the one hand, the quest for improved accountability was one of the main driving forces to implement administrative reforms. On the other hand, under NPM new forms of accountability have been introduced, especially for semi-autonomous agencies (Overman, Van Thiel and Van Genugten 2015; Schillemans, 2008; Verschuere et al. 2006). Such new types of accountability include 'downward' towards stakeholders and users (Verschuere et al. 2006) and 'horizontal' towards boards etc. that are not hierarchical superiors of agencies (Schillemans 2008). Yet these new types hardly seem to replace the relevance of the vertical dimension of accountability towards parent ministries, nor have they proven to be a solution to the new accountability concerns that were raised after agencification because of the weakening of the traditional vertical accountability to ministries.

Turning to the substance of accountability relations, Lægreid (2014, 325-326) argues that NPM reforms focus on individual managerial accountability rather than collective and political accountability, shifting the focus from 'processes and compliance with rules and input (finances) to output and results. More traditional notions of accountability, such as accountability for fairness and for processes, have been challenged by notions of increased efficiency, competition, and cost effectiveness.' These elements of managerial accountability - more individual, more managerial, different foci - correspond to a vision of politicians as strategic supervisors of agencies. In practice, this will create tensions as politicians, and civil servants alike, find it difficult to refrain from intervention, even in daily managerial matters (Pollitt 2005). As a result, they may choose to supplement existing accountability arrangements with new elements, which would in effect reduce the autonomy just granted to agencies or even exceed previous requirements (Pollitt and Bouckaert 2011, 197-198).

The Rechtsstaat tradition is characterized by an emphasis on input and procedural control, rather than output control. These different foci address very different sets of administrative values. Input control is associated with the democratic chain of delegation and accountability, while 
procedural control is in line with the obligation to follow predefined rules and procedures. Managerial values stress output control and emphasize performance and efficiency. If countries adopt the logic of the NPM, agency accountability should become focused mostly on results or performance, and require agencies to provide information ex post rather than ex ante (Moynihan and Pandey 2006; Verschuere et al. 2006). Put differently, 'managing to outputs and outcomes gives preference to results over compliance with input controls and prescribed processes' (Aucoin and Heintzman 2000, 47). For governments in a Rechtsstaat model, this is quite a change from the traditional focus on the legality of decisions and expenditures. In the analyses below we will include three kinds of accountability: on finances (as indicator of procedural control linked to the input dimension), legality (as indicator of procedural control linked to how organizations perform their tasks) and results (as indicator of performance control). ${ }^{2}$

To be sure, a shared administrative tradition does not imply that countries are identical. Therefore, a comparative analysis of national patterns of agency chief executive accountability will have to take into account country-specific trajectories. Also, different public sector organizations might emphasize different types of administrative values, and patterns of accountability might converge among similar organizations, rather than within national contexts. We outline both analytical perspectives in the following subsections.

\section{National Patterns Approach}

Following Painter and Peters (2010), our four countries represent the Rechtsstaat model. Arguably, Germany and Austria are closest to this ideal-type model, yet also the Netherlands and Switzerland have traditionally been strongly influenced by it. That said, the countries also display considerable differences (Bach and Huber 2012). For instance, Austria, Germany, and Switzerland have independent administrative courts, which is not the case for the Netherlands. Moreover, whereas Germany and to a lesser degree Austria have a separated civil service system, public sector

\footnotetext{
${ }^{2}$ More precisely, the financial accountability comprises accountability for budgeting and accountability. Also, due to a broad operationalization of results accountability, this dimension may also include accountability for financial results. We thank one of the anonymous reviewers for pointing this out. For more information on the dependent variables, see table 3 .
} 
employment in the Netherlands and Switzerland is less clearly differentiated from the private sector. Finally, all countries except for the Netherlands have a federal state structure, and it could be that federal agencies perform different tasks than national agencies. Therefore, we will control for task (policy sector) in our analysis below. We will now formulate three hypotheses on the interplay of administrative reforms and administrative traditions (see table 1 for an overview of the hypotheses).

The first hypothesis, the instrumental hypothesis (H1), assumes that administrative reforms will lead to desired effects, and that the balancing of different values in agencies' vertical accountability can be deliberately designed and changed. This perspective draws on the idea of administrative reform as institutional design by politicians aiming at the achievement of specific objectives (Painter and Yee 2011). Although administrative traditions (and particularly the Rechtsstaat tradition) are often assumed to constrain the possibilities for deliberate reforms, this does not mean that such reforms are impossible. After all, administrative traditions are only one explanatory factor for administrative reform processes (Yesilkagit 2010). Yet assuming that deliberate design is possible has important implications for our conceptual understanding of administrative traditions. Most importantly, the question is whether possible changes in the balance of administrative values imply a significant change in the nature of a country's administrative tradition (cf. Yesilkagit 2010). We will return to this question when presenting our third hypothesis.

Following the instrumental hypothesis, input and process as standards of chief executive accountability will have been replaced by output standards of accountability in countries where NPM reforms have been pursued most rigorously. Against the background of agency reforms in the four countries described above (see also Bach and Huber 2012), as well as more general assessments of administrative reforms and their effects in those countries (Hammerschmid and Meyer 2005; Pollitt and Bouckaert 2011; Proeller and Schedler 2005), we consider The Netherlands and Switzerland as more eager reformers, compared to Austria and Germany. To be sure, this hypothesis does not naively assume that traditional values have completely disappeared, but rather that performance accountability has taken a dominant position.

In contrast, the continuity hypothesis (H2) suggests a high degree of stability in administrative traditions and hence accountability patterns in all four Rechtsstaat countries. More precisely, we 
would expect high degrees of financial and legal accountability (which are associated with input and process control patterns) and low degrees of performance accountability (output control). The continuity hypothesis draws on an institutionalist argument, suggesting that reform success depends on the "cultural compatibility" between the underlying values of the reform and the national context (Christensen and Lægreid 2001; Pollitt and Bouckaert 2011). This view assumes that administrative traditions are stable and cannot be easily changed (Lynne 2006; Painter and Peters 2010).

Accordingly, accountability patterns in Rechtsstaat countries are unlikely to incorporate performance as a core value.

The third hypothesis provides some analytical middle ground between the instrumental and continuity hypotheses. A layering hypothesis (H3) suggests that reforms do not replace the existing system, but rather add new elements to the existing system through 'a process of addition, not demolition' of the traditional elements (Pollitt and Bouckaert 2011, 120; Lapsley 2008; Lodge and Gill 2011). This assumption corresponds to what Pollitt and Bouckaert (2011) have labelled the 'NeoWeberian State' (NWS), which implies a combination of traditional values such as honesty and fairness with values of frugality. Thus an administrative tradition can continue to exist, although in a slightly modified version. With regard to administrative accountability relations, the NWS implies 'a shift in the balance from ex-ante to ex-post controls, but not a complete abandonment of the former' (Pollitt and Bouckaert 2011, 119). In terms of accountability arrangements, H3 predicts an equal emphasis on financial, legal and results accountability in those countries where managerial reforms have been pursued most rigorously.

\section{Organizational Patterns Approach}

A complementary perspective suggests that patterns of chief executive accountability vary between agencies, with similar values being emphasized in similar organizations (Bach 2014; Pollitt 2006; Verhoest et al. 2010). This article focuses on two organizational characteristics: agency type and agency financing. An institutional choice perspective assumes that formal-legal structures are the result of deliberate design, and that these structures "matter" for actual patterns of decision-making 
(Christensen 2001; Painter and Yee 2011). Accordingly, differences in formal autonomy are assumed to translate into variation in the actual relationship with parent ministries, including accountability relations. This is particularly relevant for Rechtsstaat countries, where decision-makers have a limited repertoire of structural elements ("legal types") at their disposal when designing public organizations (Bach and Jann 2010). The agency type hypothesis (H4) suggests that chief executives of formally more autonomous agencies will report lower degrees of accountability on all dimensions. However, considering the central tenet of NPM that performance accountability should go hand in hand with high degrees of managerial autonomy, a more fine-grained autonomy-accountability-balance hypothesis (H5) suggests that more formally autonomous agencies are more accountable on results, but less accountable on input and process. The ideal-typical modern agency is characterized by high degrees of managerial autonomy in the use of inputs (e.g. through lump-sum budgets) and the internal management of the organization (e.g. through agency-specific personnel regulations), as well as high focus on results (Moynihan and Pandey 2006; Verschuere et al. 2006). Assuming that administrative reforms used this model as a blueprint, we would hence expect a somewhat paradoxical effect of the degree of formal autonomy on perceived levels of accountability, namely both more (results) and less (financial and legal) accountability. The mode of agency financing is also assumed to affect day-today agency governance. Arguably parent ministries have limited leverage over agencies which are fully or partially self-funded, as they are unable to use financial appropriations as a steering instrument (Pollitt 2006). A high proportion of self-generated funds may even reverse dependency relationships, as ministries may rely on agencies for revenues. Additionally, self-funded agencies will push for discretion in the use of their resources (Verhoest et al. 2010). The agency funding hypothesis (H6) suggests that higher degrees of self-funding imply lower degrees of accountability, specifically with regard to financial accountability.

$* * *$ Table $1 * * *$ 


\section{Data and Methods}

Data were collected by similar surveys of agency chief executives in all four countries. This research is part of the COBRA network, an international research project, which has been carried out in 18 countries. $^{3}$ Table 2 reports information about sample size and response rates. All response rates are above the average for surveys of senior managers answering on behalf of the entire organization (Baruch and Holtom 2008). National samples were compared to the population with regard to organizational characteristics, and found to be representative of the population in terms of potentially relevant organizational characteristics (e.g. agency type).

\section{$* * *$ Table $2 * * *$}

The questionnaires were sent to the chief executives of the entire population of agencies in the four countries, and they were asked to answer on behalf of their organization, rather than reporting their personal views. Surveying chief executives is a widespread methodological approach in comparative research on agency autonomy and accountability targeted at the organizational level of analysis (e.g. Hanretty and Koop 2012; Maggetti 2012; Verschuere et al. 2006). Although chief executives cannot be familiar with every detail of the day-to-management of their organization, their position entails a great deal of knowledge about the demands imposed on the organization by their parent ministry, which they acquire through meetings, correspondence, the budgeting process, and reporting requirements, among others.

To be sure, targeting chief executives might bias the results, as these respondents might wish to provide an overtly positive view of their organization. This is a plausible concern regarding the use of perceptional data, yet we did not find any differences between chief executives' and other respondents' answers. ${ }^{4}$ Finally, we feel confident that our respondents are well placed to make

\footnotetext{
${ }^{3}$ For more information, see: www.soc.kuleuven.be/io/cost

${ }^{4}$ In Austria, Germany, and The Netherlands, we gathered information on who actually answered the survey. Most surveys were answered by the chief executives themselves (82\% in Austria, $45 \%$ in Germany, $48 \%$ in The Netherlands). Most other respondents belonged to the senior management. To control for potential bias, we compared the responses of chief executives to other respondents (Mann-Whitney-U) regarding the dependent variables but did not find any statistically significant differences.
} 
meaningful assessments of external accountability requirements imposed on their organizations. We do need to emphasize however that our data reflect perceptions of chief executives on externally imposed accountability requirements. Earlier research has shown that formal and actual practices of autonomy and control in agencies do not always coincide (Yesilkagit and Van Thiel 2008). This should be kept in mind when discussing the outcomes of our analyses.

This article analyzes the pooled COBRA dataset comprising 453 organizations from the four continental countries under scrutiny. ${ }^{5}$ Although the survey items were largely similar, some variables had to be recoded, following the guidelines that were agreed upon in the COBRA network. ${ }^{6}$ The dependent variables are ordinal variables, which limits the possibilities for performing statistical analysis using linear regression models. Moreover, more respondents report high degrees of accountability than would be expected in a normal distribution. Therefore, in addition to descriptive statistics, non-parametric techniques are used.

\section{Results}

Table 3 summarizes the descriptive statistics. As already indicated, the distribution of the dependent variables is skewed, but nevertheless displays clear variation. Figure 1 shows clear variation per country across the three dimensions of accountability. These findings are generally supported by a rank comparison which takes into consideration the full range of the dependent variables (table 4). ${ }^{7}$ For all three dimensions, statistically significant country differences are observed, although not necessarily between all countries. Next, typical combinations of these three dimensions of accountability were investigated. The most common combination is high degrees of accountability on all three dimensions, followed by moderate or no reported accountability on all three dimensions. None of the respondents reports high accountability on performance only, and very few respondents report accountability for legality only (refuting H1).

\footnotetext{
${ }^{5}$ The sample size is slightly lower than the sum of the country samples. For instance, so-called water boards were retrospectively excluded from the Dutch sample because they do not have a parent department.

${ }^{6}$ Alternative ways of recoding did not lead to substantially different results than those reported here.

${ }^{7}$ The non-parametric Kruskal-Wallis test of equality-of-populations tests the hypothesis that several samples are from the same population by comparing the mean ranking of the dependent variable per sample (e.g. countries). In descriptive terms, higher mean ranks indicate higher values on the dependent variable (i.e. level of accountability).
} 


\section{***Table $3 * * *$}

$* * *$ Figure $1 * * *$

In terms of country-specific patterns, a sizeable number of agencies report accountability on both finances and results in The Netherlands (refuting H2), which is a very uncommon combination in both Austria and Germany. As the latter countries seem to focus least on results accountability, their observed pattern might be considered to be more in line with $\mathrm{H} 2$. That said, the overall pattern in Switzerland does not correspond to the theoretical expectation of a persistent pattern of high financial and legal and low performance accountability (i.e. H2). Accountability on both finances and legality is typical for Austria and Germany, but unusual in The Netherlands and Switzerland. Moreover, a sizeable number of Austrian agencies reports legal accountability only. Finally, the combination of legal and results accountability is typical for Switzerland, but very uncommon in Austria.

These findings suggest that country-specific reform trajectories might provide plausible explanations for dominant combinations of accountability dimensions: neither Austria nor Germany have embarked on comprehensive administrative reforms emphasizing performance management, whereas such reforms have been more prominent in The Netherlands and especially Switzerland. Hence the low relevance (but certainly not total absence) of results accountability in Austria and Germany is plausible, given the relatively low importance of managerial reforms in those countries (Bach and Jann 2010; Hammerschmid and Meyer 2005).

The analysis indicates substantial differences between countries with regard to patterns of accountability, both for single dimensions and typical combinations of financial, legal, and results accountability. The presence of different combinations of accountability (while taking into consideration different reform trajectories) can be interpreted as supportive to $\mathrm{H} 3$ which predicted the layering of accountability arrangements. 
How do patterns of agency chief executive accountability vary by organizational characteristics? According to $\mathrm{H} 4$ patterns of accountability will vary according to agency types, with distinct degrees of formal autonomy. A rank comparison indeed shows significant differences between agency types for all three dimensions of accountability (table 5). However, there is no linear relationship between formal autonomy and accountability (refuting H4). For all three dimensions, accountability levels increase with the degree of formal autonomy when comparing units of government and semi-autonomous agencies on the one hand and legally independent organizations on the other. A further increase in formal autonomy, however, coincides with lower degrees of accountability, of all three kinds, refuting the autonomy-accountability-balance hypothesis (H5). More formal autonomy is not compensated by more results accountability.

$* * *$ Table $5 * * *$

Finally, the agency funding hypothesis (H6) suggested a positive relationship between the extent of government funding and chief executive accountability (table 6). The analysis shows that chief executives of self-funded agencies report less accountability on finances and results, but these differences are (highly) significant for results accountability only (partial corroboration of H6). There is no linear relationship between agency funding and legal accountability, though. In other words, funding clearly affects accountability patterns, but not for all dimensions, and what really matters is whether agencies are fully self-funded or not.

\section{$* * *$ Table $6 * * *$}

We also performed multivariate regression analyses with additional control variables. ${ }^{8}$ These analyses partly confirm the findings on national patterns of chief executive accountability (table 7). Most importantly, all respondents report lower degrees of legal accountability compared to the

\footnotetext{
${ }^{8} \mathrm{We}$ used ordered probit models, which are appropriate to estimate relationships between ordinal dependent variables with more than two outcomes and a set of independent variables.
} 
reference country, Germany. The model indicates a significantly lower degree of financial accountability of Swiss agencies, but no significant differences between Austrian and German agencies, which was the main finding of the univariate analysis. Most surprisingly, despite different reform trajectories, there are no statistically significant country differences for results accountability when controlling for organizational characteristics (again refuting $\mathrm{H} 1$ and $\mathrm{H} 2$, potentially supporting H3). The multivariate regressions confirm previous findings on the effects of agency type on perceived accountability. However, there are still no linear relationships between autonomy and accountability (refuting H4 and H5). Finally, with regard to the agency funding hypothesis, the multivariate analysis clearly supports the previous findings (and H6).

\section{$* * *$ Table $7 * * *$}

In order to test the robustness of our models, several additional analyses were performed, which are not fully reported here. ${ }^{9}$ These tests indicate a robust effect of the agency funding regime on patterns of accountability, whereas the effects of agency type are less stable. In terms of country differences, the results for legality and results accountability are confirmed, but the results for financial accountability proved less stable. These findings suggest that the relationship between agency characteristics and accountability is moderated by national contexts. A more detailed analysis lies beyond the scope of this article, as we are mainly interested in cross-country differences.

\section{Discussion and Conclusions}

This article set out to study the accountability patterns of chief executives of agencies in four Rechtsstaat countries, testing for differences and similarities between the countries. As NPM ideals emphasize very different administrative values than the traditional approach in the Rechtsstaat model, we questioned which values would be dominant in the accountability of agency chief executives to

\footnotetext{
${ }^{9}$ These tests included the calculation of confidence intervals using the bootstrapping and the clustering options (by country) in STATA. Also, binary logistic regressions using dichotomous dependent variables and OLS regressions using five-point scales for the dependent variables (where available) were performed.
} 
their parent ministry. Several predictions were made, ranging from full adoption of NPM accountability values $(\mathrm{H} 1)$, to a predominance of traditional administrative values $(\mathrm{H} 2)$, or a mixture (H3). Moreover, we also investigated differences between different legal types of agencies (i.e. different degrees of formal autonomy, $\mathrm{H} 4$ and H5) and their financial self-sufficiency (H6).

The analyses show that many differences exist in the type and intensity of agency accountability in the four countries. None has fully adopted the NPM model in which agencies are predominantly held accountable ex post on their results. This could be attributed to the fact that the NPM ideology does not fit well with the Rechtsstaat tradition (Pollitt and Bouckaert 2011; Proeller and Schedler 2005). Whereas this tradition might have contributed to preventing managerial reforms from the outset (as in Germany), in the other countries reforms have been adopted, often with some adjustments to national traditions (cf. Smullen 2010). In all four countries, we observe a layering of accountability arrangements associated with "old" and "new" types of public sector management, as predicted by H3. Legal, financial and results accountability are found in varying combinations.

Based on these findings, we conclude that Germany is the most typical representative of the Rechtsstaat model, as it places the highest demands on legal and financial accountability out of the four countries. However, results accountability is by no means absent in Germany, which is a somewhat counterintuitive finding, given the very limited relevance of NPM reforms at the federal level of government (Pollitt and Bouckaert 2011).

In contrast, ministries in Austria impose the lowest accountability demands overall, but mostly legal accountability. This finding resonates well with scholarship underlining the highly legalist nature of the Austrian administration (Hammerschmid and Meyer 2005). Swiss chief executives report the highest attention to results accountability out of the three kinds of accountability, but also almost equally high financial accountability. The Swiss model therefore combines input with output accountability, but has less attention for legality matter. It remains to be seen whether the reforms that the Swiss government is considering (Steiner and Huber 2012), will change this picture. Finally, in the Netherlands we also see a mixture of input and output focus but reversed from the Swiss case (more input than output). 
The Dutch case appears to be somewhat exceptional (cf. Bach and Huber 2012). The conclusions about the effect of agency type (H4, H5) and agency funding (H6) can be largely attributed to the reports by Dutch agencies. For example, agencies with the highest formal autonomy (type 3) report lower accountability requirements of all kinds, which is also the case for agencies that are financially self-supportive. This could be interpreted as a nation-specific adaptation of the agency model, but it is more likely that the Netherlands is the least Rechtsstaat -like country out of the four (Pollitt and Bouckaert 2011). In Rechtsstaat countries, formal agency status is a fairly reliable predictor of agency autonomy (Bach and Huber 2012) and agency accountability. However, in the Dutch case, we did not find any linear relationships between the type of agency and accountability requirements.

Overall, we find that in all four countries results accountability is part of the gamut of accountability arrangements, but has not replaced traditional accountability values such as legality. Instead, there is a layering of accountability arrangements, which squarely fits with the notion of the NWS (Pollitt and Bouckaert 2011). More generally, we find that potentially conflicting administrative values seem to be compatible, and that the Rechtsstaat tradition is capable of accommodating supposedly "alien" managerialist values. There are however also differences, both in terms of the intensity of accountability (lowest in Austria, highest in Germany) and combinations of accountability foci (Switzerland and The Netherlands: results and financial accountability). There is variation in the intensity of accountability between different types of agencies but there is no linear relationship between degree of autonomy (and distance) and accountability. Moreover, regarding financial selfsufficiency there was only a link to results accountability. This warrants further research. Taken together these findings suggest that country and agency specific features are more important to explain agency chief executives' accountability than the overall administrative tradition of the Rechtsstaat model. Input and process accountability have not been replaced, and results accountability has not become dominant. What seems to hold for NPM adoption in general - reforms are adapted to national contexts - seems to hold for accountability as well.

Last but not least, our findings also have implications for administrative policy-making. Most importantly, the analysis shows that the Rechtsstaat model can accommodate managerial values and is 
not "immune" to results oriented management. However, this should not be overestimated as indicated by the persistence of procedural values in the most "reformist" countries in our sample, Switzerland and the Netherlands. Moreover, turning to the organizational level of analysis, the most robust finding is that chief executives of self-funded organizations perceive significantly lower accountability requirements in terms of finances (i.e. budgeting and accounting) and results. This suggests that financial self-sufficiency goes hand in hand with a loss of interest on the side of the parent ministry to hold subordinate organizations accountable. More research is necessary to determine whether this is an intended consequence or unintended.

Our analyses have several limitations that need to be recognized and addressed in future research. First, working with cross-national survey data always implies a loss of detail in the information one can include. For example, the categorization of agencies reduces the variation between the different types between countries. Although the typology of agencies used here (Van Thiel 2012) offers a tool for comparative analysis, the interpretation of which type of agency belongs to which category often remains open for debate. A cross-national categorization can never encompass all the country specific features of agencies.

Second, we have used perceptual data. Although we feel confident that our respondents are best positioned to provide data, alternative or additional research strategies could help to improve the accuracy of data, for example by analyzing accountability regulations or by using qualitative techniques. This kind of research could also shed light on the actual practices of accountability, as we know that formal arrangements and actual practices do not always coincide (Yesilkagit and Van Thiel 2008). Moreover, not all countries have implemented NPM reforms at the same time or pace, and the starting conditions at the time NPM reforms were introduced (if at all) might have been different. In the current study which uses cross-sectional data, we are not able to take those differences into account. Hence our assessment of whether managerial values have replaced traditional values of accountability is based on the assumption of a common starting situation defined by the four countries' shared administrative tradition.

Third, this article focuses on four countries with a similar state tradition. While such a similar systems design has benefits regarding the validity of our findings, it also limits the possibility of 
generalization of the effects to countries with other traditions that are considered more "receptive" of managerial reforms. Replication of this analysis is therefore necessary, not only with more countries but also with countries having other administrative traditions. In such an analysis, one could also include differences in the level of NPM reforms per country. Due to the limited number of countries we could not include such a variable at this time.

Fourth, this article has deliberately not touched upon the normative implications of introducing NPM values into Rechtsstaat countries. However, several authors (Aucoin and Heintzman 2000; König 2000; Lægreid 2014) warn that such values should in fact only be applied to managerial, non-politically salient aspects of agency activities. The data did not allow us to go into much detail about which aspects of agency tasks chief executives are held accountable for, but overall there was no effect of agency size or policy sector as proxies of political salience. Van Thiel and Yesilkagit (2014) demonstrate that differences in tasks do not significantly affect (perceived) autonomy either. However, it would be very worthwhile to investigate whether accountability requirements differ in terms of their focus (input, process or output) according to different aspects of agency tasks.

Finally, this article did not touch upon the question whether and how accountability arrangements make a difference for the performance of agencies, or for other important aspects of public management, such as citizens' trust in public institutions or preventing misconduct and corruption (Frederickson 1996; Suleiman 2003). These are important questions accountability scholars have to address in the future by turning accountability arrangements into the independent variables of their research.

\section{References}

Aucoin, Peter, and Ralph Heintzman. 2000. "The dialectics of accountability for performance in public management reform." International Review of Administrative Sciences 66 (1): 45-55. 
Bach, Tobias. 2014. "The autonomy of government agencies in Germany and Norway: explaining variation in management autonomy across countries and agencies." International Review of Administrative Sciences 80 (2): 341-61.

Bach, Tobias, and Etienne Huber. 2012. "Comparing agencification in continental countries." In Government agencies: Practices and lessons from 30 countries, edited by Koen Verhoest, Sandra van Thiel, Geert Bouckaert and Per Lægreid, 203-210. Basingstoke: Palgrave Macmillan.

Bach, Tobias, and Werner Jann. 2010. "Animals in the administrative zoo: organizational change and agency autonomy in Germany." International Review of Administrative Sciences 76 (3): 443-68.

Baruch, Yehuda, and Brooks C. Holtom. 2008. "Survey response rate levels and trends in organizational research.” Human Relations 61 (8): 1139-60.

Bovens, Mark. 2010. "Two Concepts of Accountability: Accountability as a Virtue and as a Mechanism." West European Politics 33 (5): 946-67.

Christensen, Jørgen Grønnegård. 2001. "Bureaucratic autonomy as a political asset." In Politicians, Bureaucrats, and Administrative Reform, edited by B. Guy Peters and Jon Pierre, 119-131. London, New York: Routledge.

Christensen, Tom, and Per Lægreid. 2001. "A Transformative Perspective on Administrative Reforms." In New Public Management. The transformation of ideas and practice, edited by Tom Christensen and Per Lægreid, 13-39. Aldershot: Ashgate.

Frederickson, H. G. 1996. "Comparing the Reinventing Government Movement with the New Public Administration." Public Administration Review 56 (3): 263-70.

Hammerschmid, Gerhard, Arndt Krischock, and Karin Steigenberger. 2012. "Austria." In Government agencies: Practices and lessons from 30 countries, edited by Koen Verhoest, Sandra van Thiel, Geert Bouckaert and Per Lægreid, 156-165. Basingstoke: Palgrave Macmillan. 
Hammerschmid, Gerhard, and Renate E. Meyer. 2005. "New Public Management in Austria: Local Variation on a Global Theme.” Public Administration 83 (3): 709-33.

Hanretty, Chris, and Christel Koop. 2012. "Measuring the formal independence of regulatory agencies.” Journal of European Public Policy 19 (2): 198-216.

Hood, Christopher. 1991. “A Public Management for All Seasons?” Public Administration 69 (1): 319.

König, Klaus. 2000. "The administrative state in Germany.” In Comparing public sector reform in Britain and Germany, edited by Hellmut Wollmann and Eckhard Schröter, 47-65. Aldershot: Ashgate.

Lægreid, Per. 2014. “Accountability and New Public Management.” In The Oxford Handbook of Public Accountability, edited by Mark Bovens, Robert E. Goodin, and Thomas Schillemans, 32438.

Lapsley, Irvine. 2008. “The NPM agenda: back to the future.” Financial Accountability \& Management 24 (1): 77-96.

Lodge, Martin, and Derek Gill. 2011. "Toward a New Era of Administrative Reform? The Myth of Post-NPM in New Zealand." Governance 24 (1): 141-66.

Lynn, Laurence E. 2006. Public Management: Old and new. New York, London: Routledge.

Maggetti, Martino. 2012. Regulation in practice. Essex: ECPR Press.

Moynihan, Donald P., and Sanjay K. Pandey. 2006. "Creating desirable organizational characteristics." Public Management Review 8 (1): 119-40.

Olsen, Johan P. 2006. "Maybe It Is Time to Rediscover Bureaucracy.” Journal of Public Administration Research and Theory 16 (1): 1-24. 
Overman, Sjors, Sandra van Thiel, and François Lafarge. 2014. "Resisting Governmental Control: How Semi-Autonomous Agencies Use Strategic Resources to Challenge State Coordination.” International Review of Administrative Sciences 80 (1): 172-92.

Overman, Sjors, Sandra van Thiel, and Marieke van Genugten. 2015. "Accountability after structural disaggregation: comparing agency accountability arrangements." Public Administration 93 (4):1102-1120.

Painter, Martin, and B. G. Peters. 2010. "Administrative Traditions in Comparative Perspective: Families, Groups and Hybrids.” In Tradition and Public Administration, edited by Martin Painter and B. G. Peters, 19-30. Houndmills, New York: Palgrave Macmillan.

Painter, Martin, and Wai-Hang Yee. 2011. "Task Matters: A Structural-Instrumental Analysis of the Autonomy of Hong Kong Government Bodies.” The American Review of Public Administration 41 (4): 395-410.

Pollitt, Christopher. 2001. "Convergence: The Useful Myth.” Public Administration 79 (4): 933-47.

Pollitt, Christopher. 2005. "Ministries and Agencies: Steering, Meddling, Neglect and Dependency." In Challenges to State Policy Capacity, edited by Martin Painter and Jon Pierre, 113-36. Houndmills, New York: Palgrave Macmillan.

Pollitt, Christopher. 2006. "Performance Management in Practice: A Comparative Study of Executive Agencies." Journal of Public Administration Research and Theory 16 (1): 25-44.

Pollitt, Christopher, and Geert Bouckaert. 2011. Public Management Reform. 3rd ed. Oxford: Oxford University Press.

Proeller, Isabella, and Kuno Schedler. 2005. "Change and Continuity in the Continental Tradition of Public Management.” In The Oxford Handbook of Public Management, edited by Ewan Ferlie, Laurence E. Lynn, and Christopher Pollitt, 695-71. Oxford, New York: Oxford University Press. 
Schillemans, Thomas. 2008. "Accountability in the Shadow of Hierarchy: The Horizontal Accountability of Agencies." Public Organization Review 8 (2): 175-94.

Smullen, Amanda. 2010. Translating agency reform. Basingstoke, Hampshire: Palgrave Macmillan.

Steiner, Reto, and Etienne Huber. 2012. "Switzerland." In Government agencies: Practices and lessons from 30 countries, edited by Koen Verhoest, Sandra van Thiel, Geert Bouckaert and Per Lægreid, 191-202. Basingstoke: Palgrave Macmillan.

Suleiman, Ezra N. 2003. Dismantling democratic states. Princeton, N.J. Princeton University Press.

van Thiel, Sandra. 2012. "Comparing Agencies across Countries." In Government agencies: Practices and lessons from 30 countries, edited by Koen Verhoest, Sandra van Thiel, Geert Bouckaert and Per Lægreid, 18-26. Basingstoke: Palgrave Macmillan.

van Thiel, Sandra, and Kutsal Yesilkagit. 2014. "Does task matter? The effect of task on the establishment, autonomy and control of semi-autonomous agencies." International Review of Administrative Sciences 80 (2): 318-40.

Verhoest, Koen, Paul G. Roness, Bram Verschuere, Kristin Rubecksen, and Muiris MacCarthaigh. 2010. Autonomy and control of state agencies. Basingstoke: Palgrave Macmillan.

Verhoest, Koen, Sandra van Thiel, Geert Bouckaert, and Per Lægreid, eds. 2012. Government agencies: Practices and lessons from 30 countries. Basingstoke: Palgrave Macmillan.

Verschuere, Bram, Koen Verhoest, Falke Meyers, and B. G. Peters. 2006. “Accountability and accountability arrangements in public agencies." In Autonomy and regulation: Coping with agencies in the modern state, edited by Tom Christensen and Per Lægreid, 268-98. Cheltenham: Edward Elgar.

Yesilkagit, Kutsal. 2010. "The Future of Administrative Tradition: Tradition as Ideas and Structures." In Tradition and Public Administration, edited by Martin Painter and B. Guy Peters, 145-157. Houndmills, New York: Palgrave Macmillan. 
Yesilkagit, Kutsal, and Sandra van Thiel. 2008. "Political Influence and Bureaucratic Autonomy." Public Organization Review 8 (2):137-153.

Yesilkagit, Kutsal, and Sandra van Thiel. 2012. "The Netherlands." In Government agencies: Practices and lessons from 30 countries, edited by Koen Verhoest, Sandra van Thiel, Geert Bouckaert and Per Lægreid, 179-190. Basingstoke: Palgrave Macmillan.

Ziller, Jacques. 2003. "The Continental System of Administrative Legality.” In Handbook of Public Administration, edited by Guy B. Peters and Jon Pierre, 260-68. London: Sage. 
Table 1: Hypotheses

\begin{tabular}{|l|l|}
\hline National Patterns Approach & $\begin{array}{l}\text { Chief executives are held accountable on performance rather } \\
\text { than on input and process in countries where more } \\
\text { comprehensive NPM reforms have been pursued (i.e. The } \\
\text { Netherlands and Switzerland). }\end{array}$ \\
\hline H2: Continuity hypothesis & $\begin{array}{l}\text { Chief executives are held accountable on input and process rather } \\
\text { than on performance, which reflects the shared administrative } \\
\text { tradition of the four countries. }\end{array}$ \\
\hline H3: Layering hypothesis & $\begin{array}{l}\text { Chief executives are held accountable on input, process and } \\
\text { output in countries where more comprehensive NPM reforms } \\
\text { have been pursued (i.e. The Netherlands and Switzerland). }\end{array}$ \\
\hline Organizational Patterns Approach \\
\hline H4: Agency type hypothesis & $\begin{array}{l}\text { Formally more autonomous agencies will report lower degrees of } \\
\text { accountability on all dimensions. }\end{array}$ \\
\hline $\begin{array}{l}\text { H5: Autonomy-accountability- } \\
\text { balance hypothesis }\end{array}$ & $\begin{array}{l}\text { More formally autonomous agencies are more accountable on } \\
\text { results, but less accountable on input and process. }\end{array}$ \\
\hline H6: Agency funding hypothesis & $\begin{array}{l}\text { The more the agency budget is self-funded, the lower its financial } \\
\text { accountability. }\end{array}$ \\
\hline
\end{tabular}


Table 2: The COBRA survey in four Continental European countries

\begin{tabular}{|l|r|r|r|r|}
\hline & The Netherlands & Austria & Germany & Switzerland \\
\hline Year of survey & 2006 & 2009 & 2008 & 2009 \\
\hline Sample / Population (N) & $219 / 574$ & $68 / 175$ & $73 / 122$ & $111 / 147$ \\
\hline Response rate (\%) & 38.2 & 38.9 & 58.9 & 75.5 \\
\hline
\end{tabular}

Note: More information on the COBRA survey and the individual country surveys can be found in the introductory chapter and the respective country chapters of Verhoest et al. (2012) 
Table 3: Descriptive statistics, all variables

\begin{tabular}{|c|c|c|c|c|c|}
\hline \multicolumn{4}{|l|}{ Dependent Variables } & $\mathbf{N}$ & $\%$ \\
\hline \multirow{4}{*}{$\begin{array}{l}\text { Financial Accountability: To what extent } \\
\text { is the top management of the } \\
\text { organization accountable to the } \\
\text { oversight authority for budgeting and } \\
\text { accounting? }\end{array}$} & \multicolumn{3}{|c|}{ not at all } & 25 & 7.25 \\
\hline & \multicolumn{3}{|c|}{ to some extent } & 104 & 30.14 \\
\hline & \multicolumn{3}{|c|}{ to a large extent } & 216 & 62.61 \\
\hline & \multicolumn{3}{|l|}{ total } & 345 & 100.00 \\
\hline \multirow{4}{*}{$\begin{array}{l}\text { Legal Accountability: To what extent is } \\
\text { the top management of the } \\
\text { organization accountable to the } \\
\text { oversight authority for legality and rule } \\
\text { compliance? }\end{array}$} & \multicolumn{3}{|c|}{ not at all } & 33 & 9.76 \\
\hline & \multicolumn{3}{|c|}{ to some extent } & 120 & 35.50 \\
\hline & \multicolumn{3}{|c|}{ to a large extent } & 185 & 54.73 \\
\hline & \multicolumn{3}{|c|}{ total } & 338 & 100.00 \\
\hline \multirow{4}{*}{$\begin{array}{l}\text { Results Accountability: To what extent } \\
\text { is the top management of the } \\
\text { organization accountable to the } \\
\text { oversight authority for goal } \\
\text { achievement and results? }\end{array}$} & \multicolumn{3}{|c|}{ not at all } & 23 & 6.80 \\
\hline & \multicolumn{3}{|c|}{ to some extent } & 128 & 37.87 \\
\hline & \multicolumn{3}{|c|}{ to a large extent } & 187 & 55.33 \\
\hline & \multicolumn{3}{|c|}{ total } & 338 & 100.00 \\
\hline \multicolumn{6}{|l|}{ Independent Variables } \\
\hline \multirow[t]{5}{*}{ Country } & \multicolumn{3}{|c|}{ The Netherlands (NL) } & 206 & 45.47 \\
\hline & \multicolumn{3}{|c|}{ Austria $(A)$} & 65 & 14.35 \\
\hline & \multicolumn{3}{|c|}{ Germany (GER) } & 73 & 16.11 \\
\hline & \multicolumn{3}{|c|}{ Switzerland $(\mathrm{CH})$} & 109 & 24.06 \\
\hline & \multicolumn{3}{|c|}{ Total } & 453 & 100.00 \\
\hline \multirow[t]{4}{*}{$\begin{array}{l}\text { Agency Type: according to typology by } \\
\text { van Thiel (2012) }\end{array}$} & \multicolumn{3}{|c|}{$\begin{array}{l}\text { unit of government and semi- } \\
\text { autonomous agencies (type } 1 \text { ) }\end{array}$} & 169 & 37.56 \\
\hline & \multicolumn{3}{|c|}{$\begin{array}{l}\text { legally independent } \\
\text { organizations (type 2) }\end{array}$} & 123 & 27.33 \\
\hline & \multicolumn{3}{|c|}{ foundations (type 3) } & 158 & 35.11 \\
\hline & \multicolumn{3}{|l|}{ total } & 450 & 100.00 \\
\hline $\begin{array}{l}\text { Funding: What is the main source of } \\
\text { funding of your organization? }\end{array}$ & $\begin{array}{l}\text { solel } \\
\text { or go }\end{array}$ & $\begin{array}{l}\text { ed by pa } \\
\text { nent }\end{array}$ & ministry & 134 & 37.64 \\
\hline & $\begin{array}{l}\text { mixe } \\
\text { gove }\end{array}$ & $\begin{array}{l}\text { predomi } \\
\text { ital bodi }\end{array}$ & & 112 & 31.46 \\
\hline & $\begin{array}{l}\text { mixe } \\
\text { sourc }\end{array}$ & $\begin{array}{l}\text { predomi } \\
\text { income }\end{array}$ & tly other & 88 & 24.72 \\
\hline & $\begin{array}{l}\text { solely } \\
\text { incluc }\end{array}$ & $\begin{array}{l}\text { ed from } \\
\text { elf-gener }\end{array}$ & $\begin{array}{l}\text { er sources } \\
\text { d income }\end{array}$ & 22 & 6.18 \\
\hline & total & & & 356 & 100.00 \\
\hline Control variables & & & & & \\
\hline Economic Policy: according to United & no & & & 308 & 67.99 \\
\hline Nations Classification of Functions of & yes & & & 145 & 32.01 \\
\hline Government (COFOG) & total & & & 453 & 100.00 \\
\hline Social and Welfare Policy: comprises & no & & & 287 & 63.36 \\
\hline several COFOG categories: housing and & yes & & & 166 & 36.64 \\
\hline $\begin{array}{l}\text { community amenities; health; } \\
\text { recreation, culture and religion; } \\
\text { education; social protection }\end{array}$ & total & & & 453 & 100.00 \\
\hline Budget (in 1.000.000 EUR) (for the & $N$ & Mean & Std. Dev. & Min & Max \\
\hline $\begin{array}{l}\text { regression analysis z-scores are used to } \\
\text { ensure cross-country comparability) }\end{array}$ & 356 & 468.00 & 2931.84 & 0 & 43680 \\
\hline
\end{tabular}


Table 4: Agency chief executive accountability by country (mean ranks)

\begin{tabular}{|l|r|r|r|}
\hline & Finances & Legality & Results \\
\hline The Netherlands & 177.96 & 163.16 & 174.78 \\
\hline Austria & 150.18 & 178.05 & 140.24 \\
\hline Germany & 191.47 & 202.13 & 167.39 \\
\hline Switzerland & 166.71 & 148.68 & 180.67 \\
\hline chi-square statistics (with ties) & $8.361^{* *}$ & $17.422^{* * *}$ & $8.439^{* *}$ \\
\hline$N$ & 345 & 338 & 338 \\
\hline
\end{tabular}

Notes: Kruskal-Wallis equality of populations rank test; ${ }^{* * *} p<.01 ;{ }^{* *} p<.05 ;{ }^{*} p<.10$ 
Table 5: Agency chief executive accountability by agency type (mean ranks)

\begin{tabular}{|l|r|r|r|}
\hline & Finances & Legality & Results \\
\hline unit of government and semi-autonomous & 172.48 & 174.95 & 172.30 \\
\hline legally independent organizations & 194.43 & 187.67 & 188.31 \\
\hline foundations & 156.00 & 143.17 & 148.61 \\
\hline chi-square statistics (with ties) & $9.380^{* * *}$ & $12.801^{* * *}$ & $9.784^{* * *}$ \\
\hline$N$ & 345 & 338 & 338 \\
\hline
\end{tabular}

Notes: Kruskal-Wallis equality of populations rank test; ${ }^{* * *} p<.01 ;{ }^{* *} p<.05 ;{ }^{*} p<.10$ 
Table 6: Agency chief executive accountability by type of funding (mean ranks)

\begin{tabular}{|l|r|r|r|}
\hline & Finances & Legality & Results \\
\hline $\begin{array}{l}\text { solely funded by parent ministry or (other } \\
\text { levels of) government }\end{array}$ & 163.42 & 154.35 & 161.19 \\
\hline $\begin{array}{l}\text { mixed but predominantly governmental } \\
\text { bodies }\end{array}$ & 165.29 & 163.90 & 162.21 \\
\hline $\begin{array}{l}\text { mixed but predominantly other sources of } \\
\text { income }\end{array}$ & 159.30 & 150.23 & 159.66 \\
\hline $\begin{array}{l}\text { solely funded from other sources including } \\
\text { self-generated income }\end{array}$ & 122.70 & 159.14 & 92.61 \\
\hline chi-square statistics (with ties) & 5.225 & 1.501 & $13.308^{* * *}$ \\
\hline N & 320 & 313 & 313 \\
\hline
\end{tabular}

Notes: Kruskal-Wallis equality of populations rank test; ${ }^{* * *} p<.01 ;{ }^{* *} p<.05 ;{ }^{*} p<.10$ 
Table 7: Accountability of agency chief executives in Germany, Austria, Switzerland and The Netherlands

\begin{tabular}{|c|c|c|c|c|c|c|}
\hline & \multicolumn{2}{|c|}{ Finances } & \multicolumn{2}{|c|}{ Legality } & \multicolumn{2}{|c|}{ Results } \\
\hline & coefficient & p-value & coefficient & p-value & coefficient & p-value \\
\hline The Netherlands & -.31 & .21 & $-.70 * * *$ & .00 & -.06 & .78 \\
\hline Austria & -.38 & .13 & $-.44^{*}$ & .10 & -.22 & .35 \\
\hline Switzerland & $-.34^{*}$ & .08 & $-.69 * * *$ & .00 & .20 & .29 \\
\hline $\begin{array}{l}\text { Legally } \\
\text { independent } \\
\text { organizations }\end{array}$ & $.43 * *$ & .04 & .22 & .28 & .30 & .13 \\
\hline Foundations & -.17 & .39 & $-.43 * *$ & .02 & -.31 & .10 \\
\hline $\begin{array}{l}\text { Mixed but } \\
\text { predominantly } \\
\text { governmental } \\
\text { bodies }\end{array}$ & -.08 & .68 & -.15 & .42 & -.10 & .60 \\
\hline $\begin{array}{l}\text { Mixed but } \\
\text { predominantly } \\
\text { other sources of } \\
\text { income }\end{array}$ & -.26 & .23 & -.11 & .60 & -.29 & .18 \\
\hline $\begin{array}{l}\text { Solely funded from } \\
\text { other sources } \\
\text { including self- } \\
\text { generated income }\end{array}$ & $-.83 * *$ & .03 & -.18 & .65 & $-.83 * *$ & .03 \\
\hline Economic Policy & .11 & .56 & .01 & .95 & .18 & .34 \\
\hline $\begin{array}{l}\text { Social and Welfare } \\
\text { Policy }\end{array}$ & -.06 & .77 & .21 & .28 & 22 & .23 \\
\hline Budget (z-score) & .00 & .94 & .03 & .61 & .06 & .32 \\
\hline $\mathrm{N}$ & 307 & & 301 & & 301 & \\
\hline Wald chi-square & $23.30 * *$ & & $28.07 * * *$ & & $25.57 * * *$ & \\
\hline Pseudo R2 & .05 & & .05 & & .05 & \\
\hline
\end{tabular}

Notes: Ordered probit regressions, ${ }^{* * *} p<.01 ;{ }^{* *} p<.05 ;{ }^{*} p<.10$, cut-off points omitted 
Figure 1: Agency chief executive accountability in Continental European countries (answer category "to a large extent")

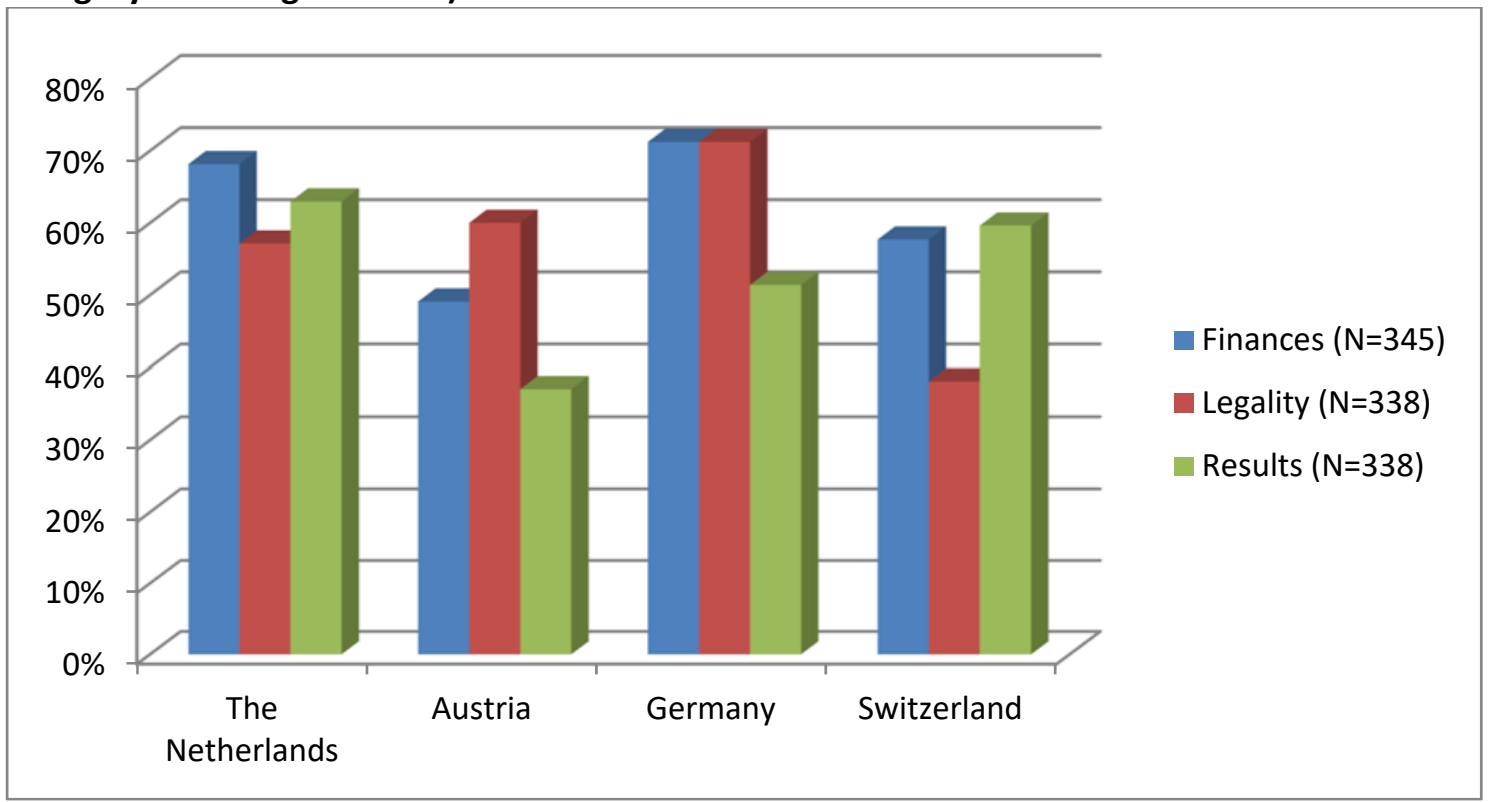

